www.jmscr.igmpublication.org

Impact Factor 5.84

Index Copernicus Value: 83.27

ISSN (e)-2347-176x ISSN (p) 2455-0450

crossref DOI:_https://dx.doi.org/10.18535/jmscr/v5i7.31

Journal Of Medical Science And Clinical Research

\title{
A study of use of Tunica Vaginalis flap in anterior urethral reconstruction
}

\author{
Authors \\ Frank Davis Daniel ${ }^{1}$, Selvakumar Soman ${ }^{2}$, Kannan Subramanian Ramasamy ${ }^{3}$ \\ ${ }^{1,2,3}$ Department of Urology, Govt. Kanyakumari Medical College, Nagercoil, Tamilnadu, India \\ Corresponding Author \\ Selvakumar Soman \\ Dept of Urology, Govt. Kanyakumari Medical College, Nagercoil, Tamilnadu, India
}

\section{Introduction}

Hypospadias is the most common congenital anomaly of penis [1]. Surgical correction of proximal hypospadias is a technically challenging. Such surgeries are associated with maximum number of failures and results in cripples. Reoperation of failed childhood hypospadias repair is seriously bothersome and is surgeon's nightmares because of lack of abundant penile and prepuce skin for urethroplasty and penile shaft coverage. Among the various complications of childhood hypospadias repair, partial disruption with urethrocutaneous fistula \&complete disruption with pan urethral strictures and ueretro cutaneous fistula are most frustrating problem for urologists. But there is no best single technique to repair.

By using a water-tight second layer during reoperation, incidence of urethrocutaneous fistula recurrence can be reduced. Tunica vaginalis flap is used to provide robust cover to neourethra. It also provides a barrier between suture lines. It has a different blood supply from internal spermatic fascia \& not depends on penile skin vascularity.

Long segment penile urethral strictures with urethro cutaneous fistula following childhood hypospadias repair are again a difficult surgical task. Most of times there is tissue shortage to cover such a long narrrowed urethral segments. These type of strictures are associated with complications most of the time. Tunica vaginalis flap has a definitive role in stage II repair of such pan urethral strictures to prevent urethrocutaneous fistula and for penile cosmesis.

\section{Aim of the study}

To assess the efficacy and results of tunica vaginalis flap as an interposing layer in reoperative hypospadias complications like long segment anterior urethral strictures and urethrocutaneous fistulas.

\section{Methodology}

Study Design: Prospective study

Duration: January 2015 to May 2017

Institute: Government Kanyakumari Medical College, Nagercoil.

\section{Patient Selection}

\section{Inclusion Criteria}

1. Patients with post childhood hypospadias repair urethrocutaneous fistula. 
2. Patients with post hypospadias repair long segment penile urethral stricture for which stage I Johanson's urethroplasty was already done.

3. Patients greater than 13 years of age.

\section{Exclusion Criteria}

1. Cases with previous scrotal surgery (Hydrocele repair or orchidopexy)

2. Cases requiring salvage perineal urethrostomy

3. Cases with perineal urethro cutaneous fistula

\section{Pre-operative variables}

- Age

- Duration of symptoms

- Uroflowmetry

- AUG

- Cystoscopy

- Previous history of open or endoscopic urethral surgery and dilatation

- Review of previous operative records

- Type of Hypospadias

- Type of initial procedure in childhood

- Number of fistulae and associated strictures

- Follow up

\section{Operative technique}

For post hypospadias urethrocutaneous fistula, initially urethra was distended with povidone iodine to identify the number of fistulas. The tract is traced to the retubularized urethra and fistulous tract removed. Fistula closed with inverting sutures \& reinforced with tunica vaginalis flap. Testis was delivered by a separate scrotal incision and tunica vaginalis flap was harvested which was in turn transferred through a subcutaneous tunnel to fistula site.

TVF was harvested by incising near testicular inferior pole and tongue of parietal layer of TVF developed with due care to prevent ductus differns and spermatic vessels injury. We must achieve perfect hemostasis and replace testis in to hemiscrotum. Serosal surface of TVF placed over neourethra as interposing layer. 4-0 absorbable tacking stitches done to fix flap to Bucks fascia. Scrotal hemostasis should be achieved.

For long penile urethra stricture, second stage was done at least 6 months following stage I repair, two asymmetric vertical incisions placed on penile skin on side of the plate and tubularisation done over 16-F silicone urethral catheter by 4-0 polyglactin sutures. An interposing layer of tunica vaginalis was drawn onto neourethra and fixed.

\section{Post-operative - Follow up}

- UC fistula closure alone - $10^{\text {th }}$ POD catheter removal

- Staged repair - $21^{\text {st }}$ POD - catheter removal after performing peri-catheter study

- Follow up at 3, 6 \& 12 months Uroflowmetry and if needed AUG and cystoscopy

Parameters assessed include

Immediate complications

○ Wound infection

- Scrotal haematoma

○ Presence of Leak

- Splaying

- Delayed complication

- Meatal stenosis.

- Failure leading to urethrocutaneous fistula and

o Re-operation

\section{Results}

Study group

\section{Age distribution:-}

A total of 12 cases (15 to 35 years) of reoperative hypospadias were included. 
Chart 1: Age wise distribution of cases

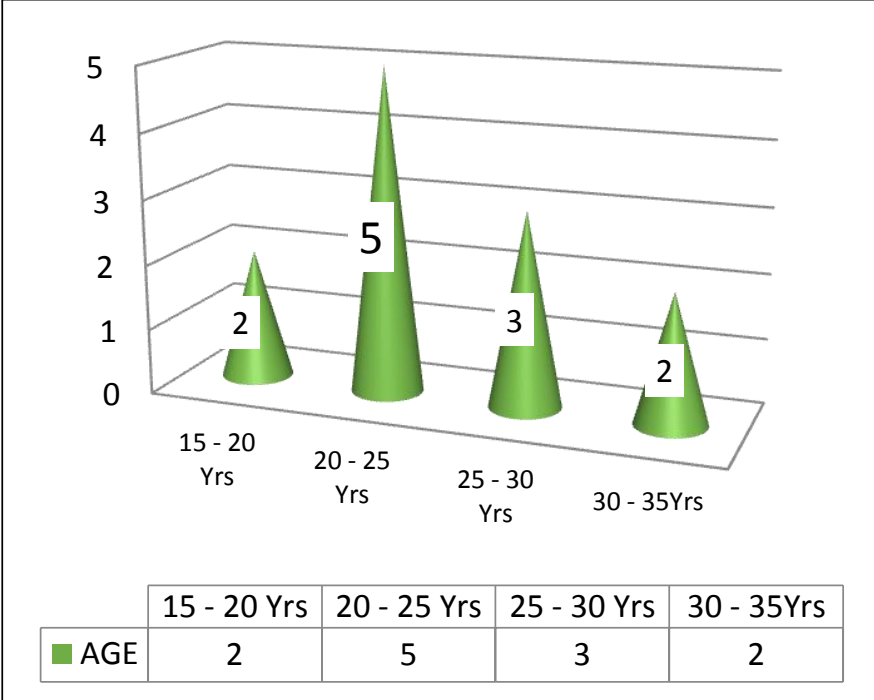

Table 1: Cases at presentation

\begin{tabular}{|l|c|c|}
\hline Clinical Presentation & No. of cases & Percentage \\
\hline Stricture with fistulae & 8 & 66.67 \\
\hline UC fistula & 4 & 33.33 \\
\hline
\end{tabular}

Table 2: Initial procedure done for hypospadias

\begin{tabular}{|l|c|c|c|c|}
\hline $\begin{array}{l}\text { Initial } \\
\text { Procedure } \\
\text { done }\end{array}$ & $\begin{array}{c}\text { Penoscrotal } \\
\text { hypospadias }\end{array}$ & $\begin{array}{c}\text { Proximal } \\
\text { penile }\end{array}$ & $\begin{array}{c}\text { Mid penile } \\
\text { hypospadias }\end{array}$ & Total \\
\hline $\begin{array}{l}\text { Theirsch-duplay } \\
\text { principle }\end{array}$ & 0 & 1 & 5 & 6 \\
\hline $\begin{array}{l}\text { Snodgrass TIP } \\
\text { procedure }\end{array}$ & 0 & 0 & 3 & 3 \\
\hline $\begin{array}{l}\text { Inner preputial } \\
\text { skin } \\
\text { tubularisation }\end{array}$ & 1 & 2 & & 3 \\
\hline Total & 1 & 3 & 8 & 12 \\
\hline
\end{tabular}

The initial surgery done in all our cases are shown in the table above

Chart 2 - Initial Type Of Hypospadias

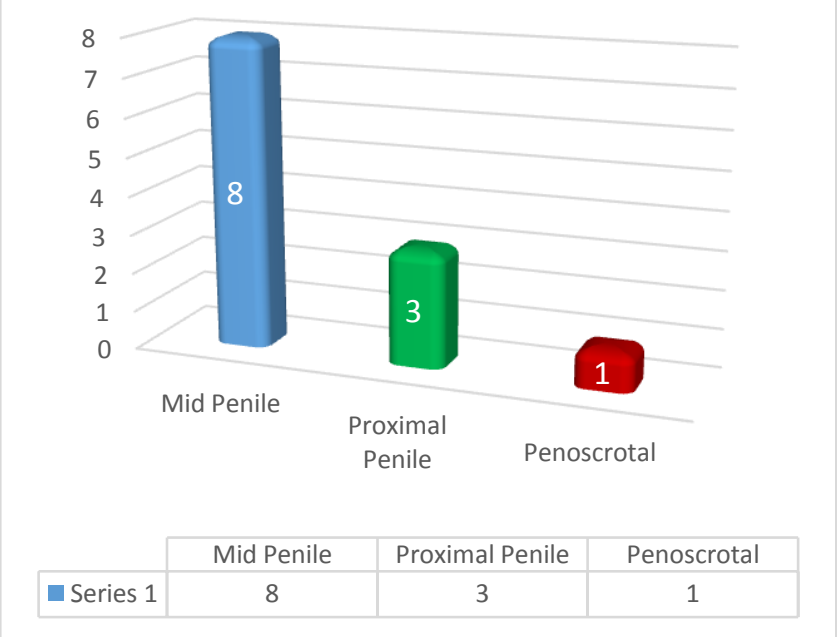

Chart 3 - Current Diagnosis

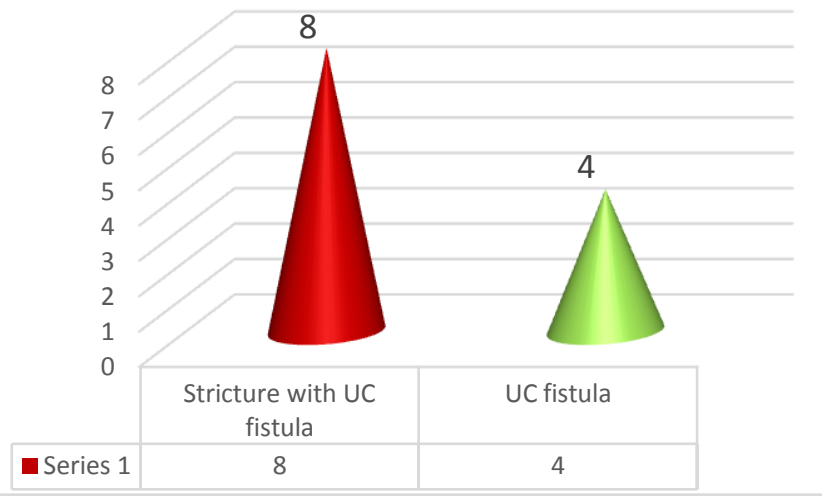

Total number of fistulae present in the patients is given below

Chart 4: Number of fistulae in patients

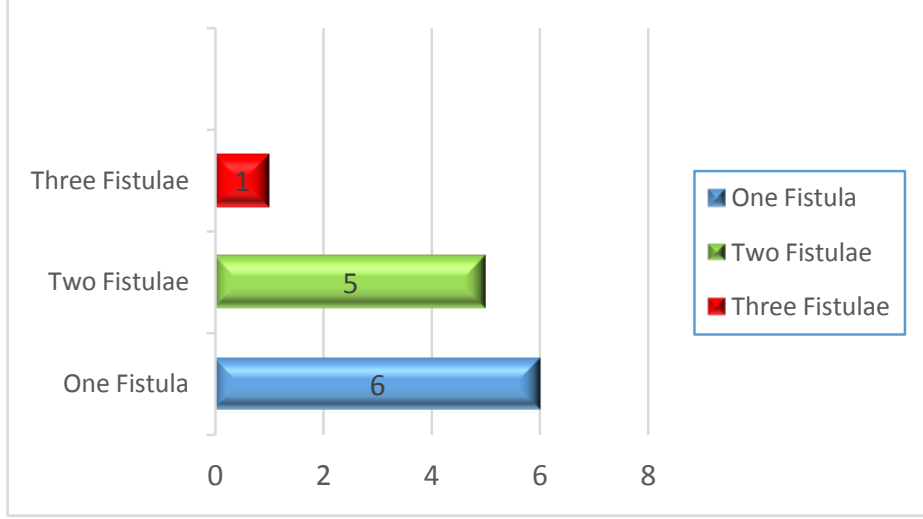

Table 3: Procedure done in patient at our centre.

\begin{tabular}{|l|l|l|}
\hline Procedure & No. of cases & $\%$ \\
\hline $\begin{array}{l}\text { Two stage repair with TVF } \\
\text { cover }\end{array}$ & 8 & 66.67 \\
\hline $\begin{array}{l}\text { Single stage repair with } \\
\text { TVF cover }\end{array}$ & 4 & 33.33 \\
\hline
\end{tabular}

We performed the above procedures in the study group. All cases had tunica vaginalis flap interposed over the repair. 


\begin{tabular}{|l|l|}
\hline JMSCR Vol||05||Issue||07||Page 24494-24500||July & 2017 \\
\hline
\end{tabular}

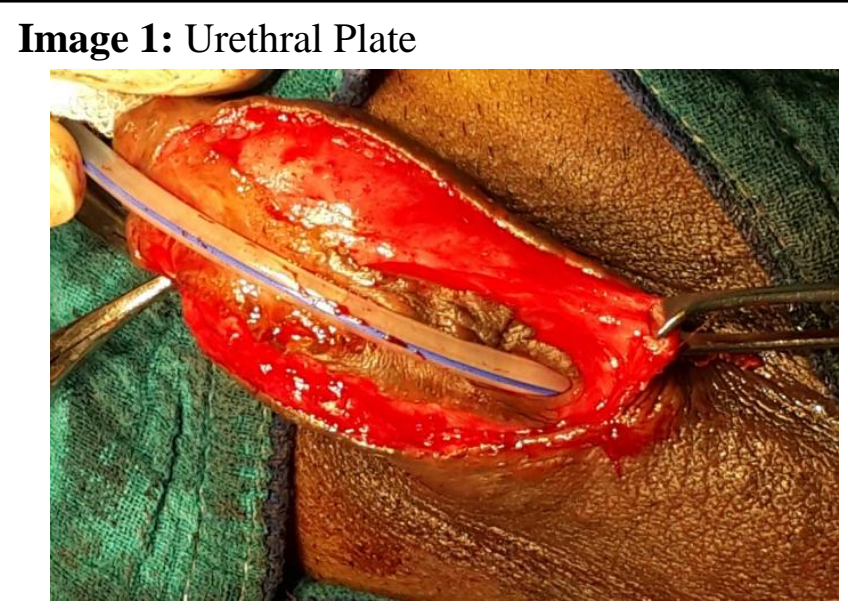

Image 2: Harvesting of tunica vaginalis flap

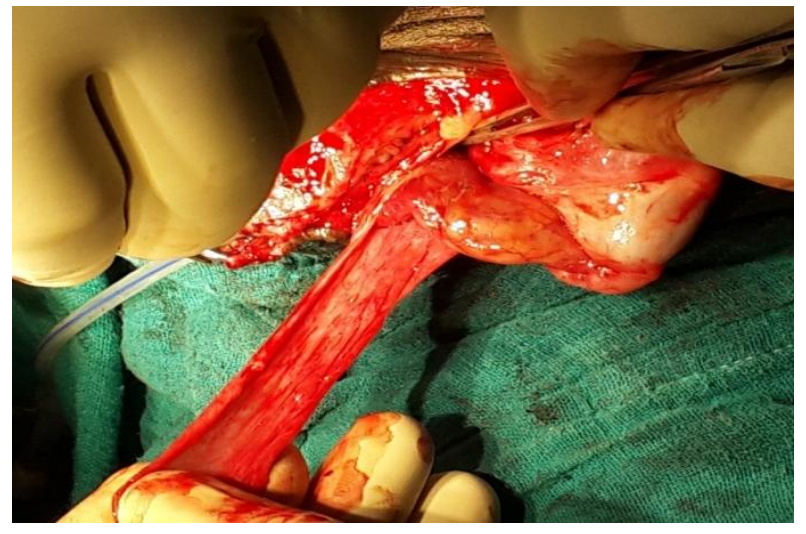

Image 3: Urethral plate Tubularisation

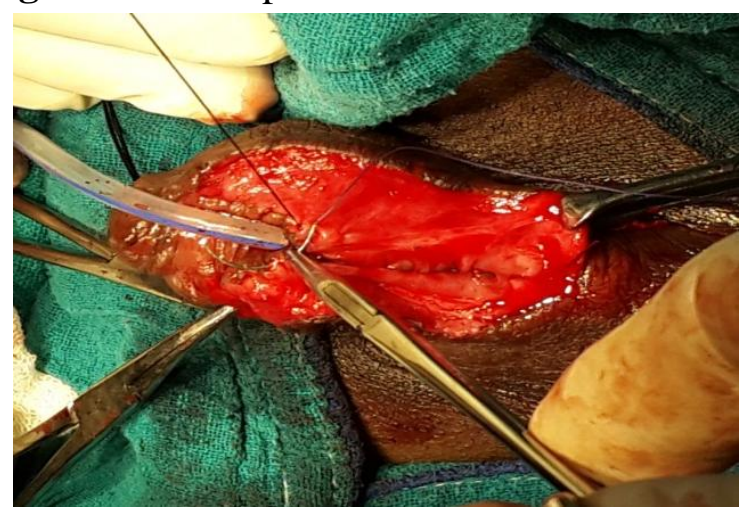

Image 4: Tunica vaginalis flap secured over the neo urethra

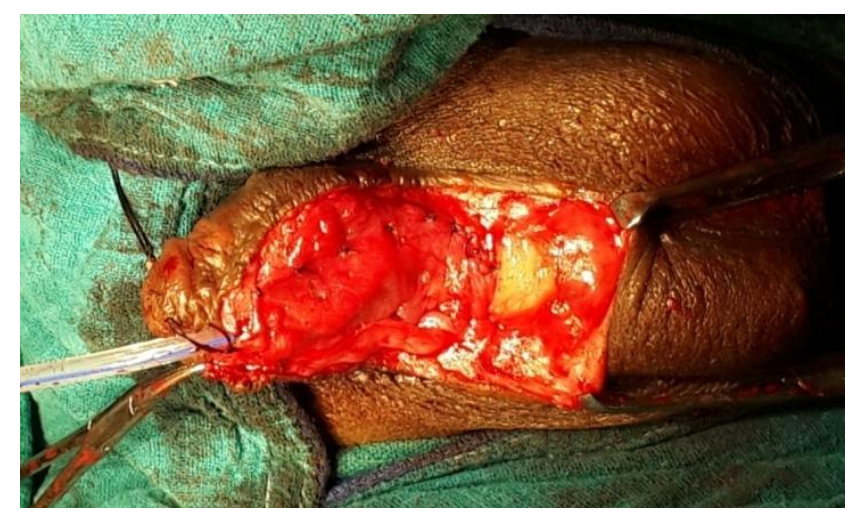

\section{Image 5: Skin Cover}

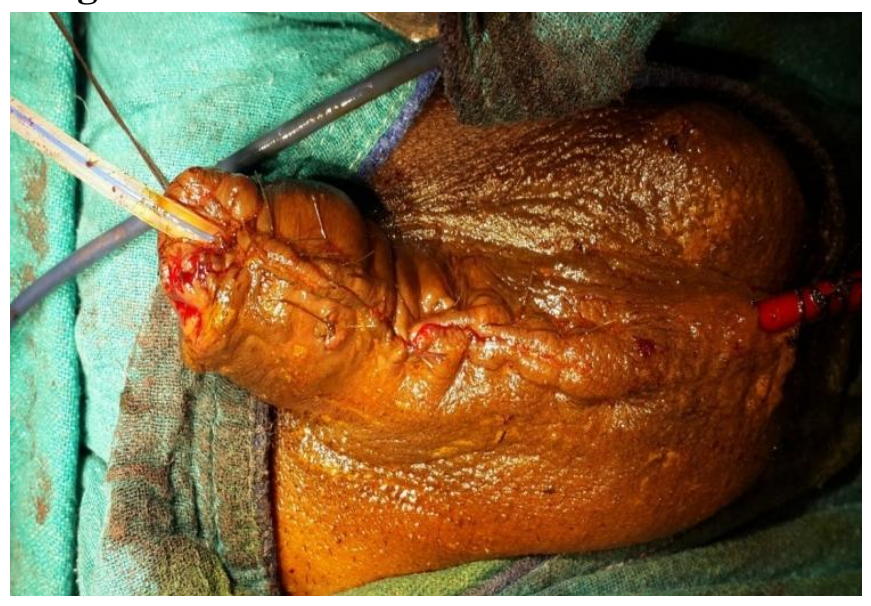

Image 6 - Pericatheter Study at POD 21

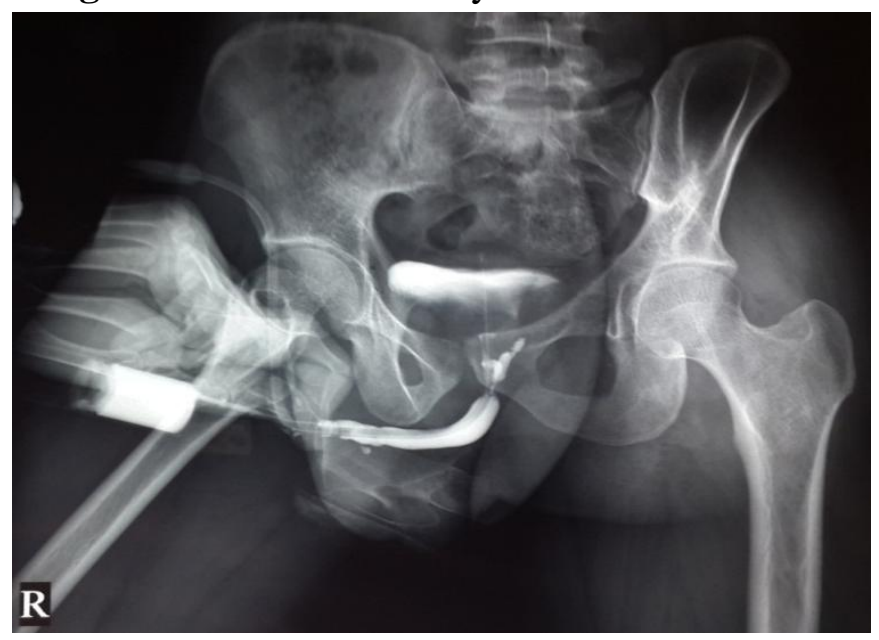

AUG demonstrating lack of extravasation of the contrast.

Image 7 Post Operative Day 30

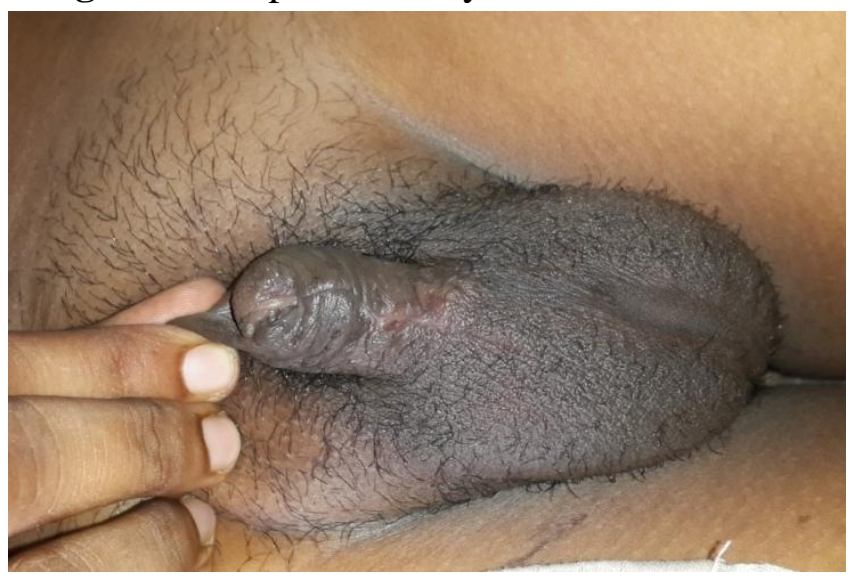


Chart 5 - Current Procedure

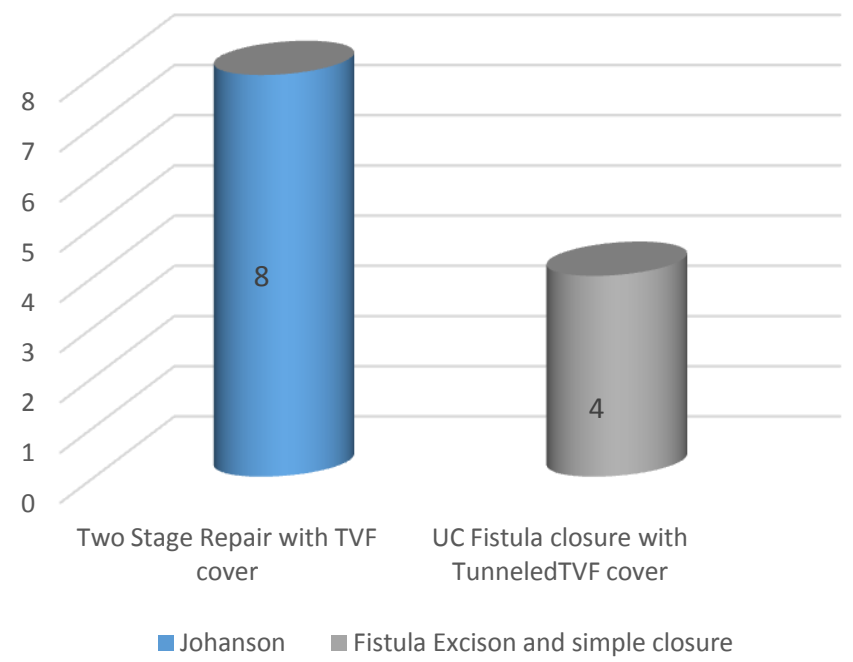

Chart 6: Flow chart showing patient surgeries and outcomes

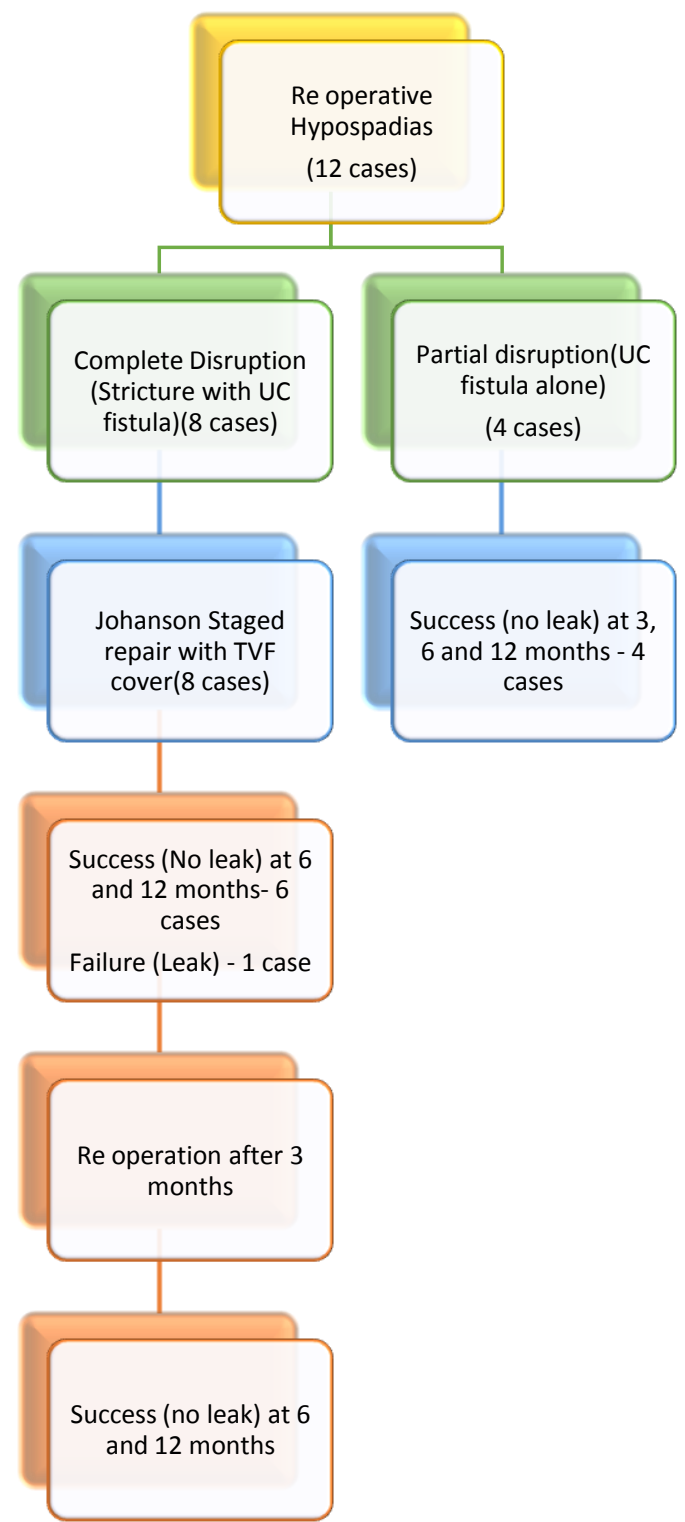

Chart 7 - Results

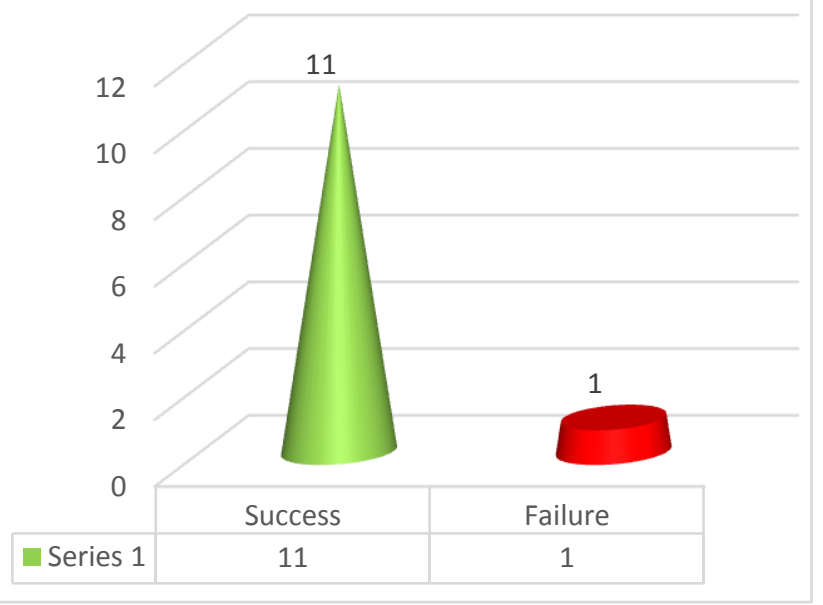

Chart 8: Complication of surgery in our study

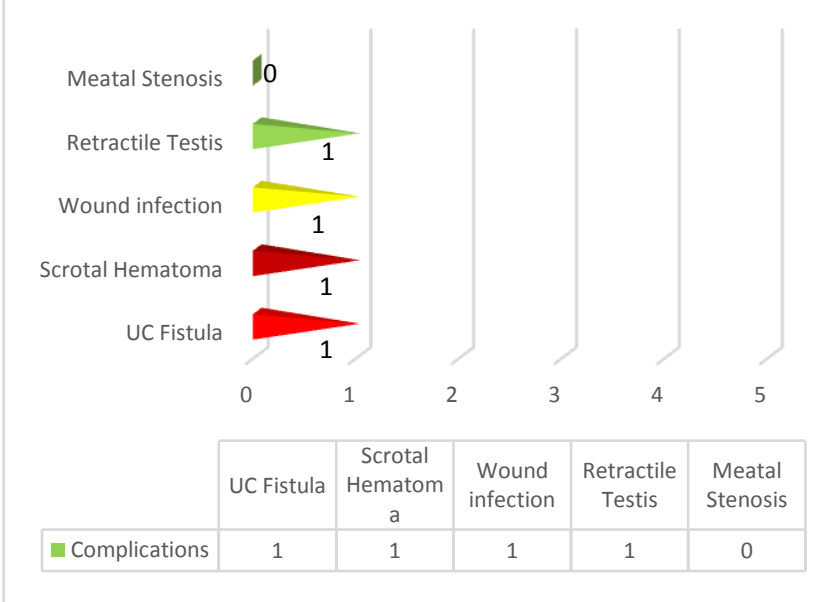

Chart 10 - OUR STUDY VARIABLES

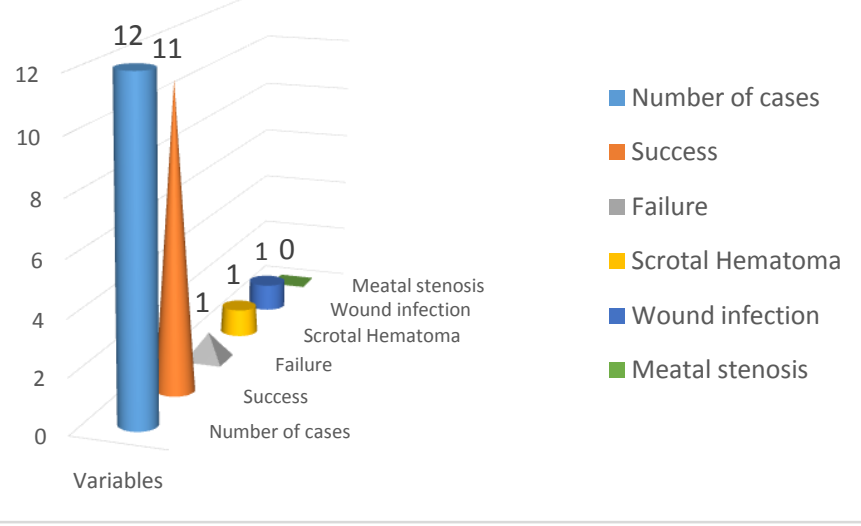

\section{Discussion}

In spite of improvements in hypospadias surgical techniques, many patients present with failed repairs. Surgical repair of such failed cases is 
always a challenging undertaking. Most common complication of these failed previous surgeries is urethro cutaneous fistula. Many techniques suggested in these situations like repaired urethra buried in the scrotum $^{2}$,staged repair ${ }^{3,4}$, overlapping denuded subcutaneous tissue ${ }^{4}$, adjacent local spongiosus tissues and rotating skin flaps ${ }^{5}$.

Factors limiting successful outcome are dense scarring, reduced vascularity and lack of prepuce and sufficient penile shaft skin. Dorsal subcutaneous option is not available mostly because it is lost in previous surgeries. But many still continue to use the adjacent genital tissue like dartos as a covering layer.

Snow introduced the tunica vaginalis flap (parietal layer) to cover the neo-urethra ${ }^{6,7}$. The place of this flap in hypospadias surgery is more than that. It is also used for substitution urethroplasty successfully. The advantage in redo cases ${ }^{8,}{ }^{9}$ it has its vascular supply from outside source and not relies on vascularity of local genital tissues, which might be scarred or destroyed due to previous repairs. Flap can be developed of sufficient length of the pedicle to cover entire neourethra till the distal neo meatus. Dissection of flap is not difficult. Only drawback is that if pedicle length is inadequate, it results in tethering of testis.

After initial hypospadias repair, urethral stricture may occur decades later. Perineal urethrostomy might be the only treatment option for such long segment urethral stricture. This stresses the importance of lifelong follow up in such situations to detect such complications at earliest state.

In our study we have assessed the effectiveness of tunica vaginitis flap in preventing urethro cutaneous fistula. We applied it as an interposing waterproof layer over the neo urethra either after closure of isolated fistula or after second stage repairs of the complete urethral disruption.

Our study has $91.67 \%$ success rate (no urine leak) and $8.33 \%$ failure rate (urine leak). Our success rate was compared to other studies, which was from $71.4 \%$ to $100 \%$. (Mean was $93.1 \%$ )

We followed our case for 12 months. With every visit at $3^{\text {rd }}, 6^{\text {th }}$ and $12^{\text {th }}$ month, none of our patient required AUG or uroflowmetry in the follow up. The results of our study were comparable with other studies as shown in the table below.

Table 4: Comparing outcome of our study with other studies

\begin{tabular}{|c|c|c|c|c|c|c|c|c|}
\hline \multicolumn{2}{|l|}{ Variables } & $\begin{array}{c}\text { SharmaN et } \\
\mathrm{al}^{10}\end{array}$ & $\frac{\text { Y.S Singh }}{\text { Kadian et al }^{11}}$ & $\frac{\text { Landau EH }}{\text { et }^{8} l^{8}}$ & $\frac{\text { Xue WY }}{\text { et al }^{12}}$ & $\begin{array}{c}\text { Routh JC et } \\
\mathrm{al}^{13}\end{array}$ & $\begin{array}{l}\text { Ahmed M. } \\
\text { Khairi et } \mathrm{al}^{14}\end{array}$ & Our study \\
\hline \multicolumn{2}{|l|}{ No. of patients } & 18 & 14 & 14 & 38 & 16 & 14 & 12 \\
\hline \multicolumn{2}{|c|}{ Success (No UC Fistula) } & $\begin{array}{c}17 \\
(94.4 \%)\end{array}$ & $\begin{array}{c}13 \\
(92.8 \%)\end{array}$ & 14 & 38 & 16 & $\begin{array}{c}10 \\
(71.4 \%)\end{array}$ & $\begin{array}{c}11 \\
(91.67 \%)\end{array}$ \\
\hline \multicolumn{2}{|c|}{ Failure (UC Fistula) } & $\begin{array}{c}1 \\
(5.5 \%) \\
\end{array}$ & $\begin{array}{c}1 \\
(7 \%) \\
\end{array}$ & 0 & 0 & 0 & $\begin{array}{c}4 \\
(29.6 \%) \\
\end{array}$ & $\begin{array}{c}1 \\
(8.33 \%)\end{array}$ \\
\hline \multirow[t]{3}{*}{ Complications } & Scrotal Hematoma & 0 & 1 & 0 & 0 & 0 & 1 & 1 \\
\hline & Wound Infection & 0 & 0 & 0 & 0 & 0 & 1 & 1 \\
\hline & Meatal Stenosis & 0 & 0 & 0 & 0 & 0 & 1 & 0 \\
\hline \multicolumn{2}{|c|}{ Follow up months } & 6 & 12 & 44 & 12 & 18 & 9 & 12 \\
\hline
\end{tabular}

\section{Limitation of our study}

Small sample size (12) with short follow-up duration (12 months). Large, RCTs with long follow up period is essential to confirm our result and to assess the efficacy of tunica vaginalis flap in urethrocutaneous fistula prevention. However this may not be feasible as only a small subset of patients following hypospadias repair require a reoperation and hence designing such a study may not be possible.

\section{Conclusion}

Tunica vaginalis flap reinforcement is an excellent and should always be in mind for reoperative hypospadias, especially when the local genital tissues appears to be scarred, tunica vaginalis flap 
as a second layer provides a well vascularised cover for adequate healing. Because of its robust nature, minor disruption of neourethral suture site tend to heal without forming fistula if urethral repair is otherwise done meticulously

\section{References}

1. Baskin LS. Hypospadias and urethral development. J Urol 2000;163:951-6.

2. Bracka A. Hypospadias repair: the twostage alternative. Br J Urol 1995;76:31-41.

3. Snodgrass, Elmore J. Initial WT experience with staged buccal graft (Bracka) hypospadias reoperations. J Urol 2004;172:1720-4

4. Aslan G, Karg E, Erdogan B. Use of Circular Subcutaneous Tissue Flaps to Prevent Fistulas in Urethroplasty. Annals of Plastic Surgery 2001;46:86-7

5. Snow BW, Cartwright PC, Unger $\mathrm{K}$. Tunica vaginalis blanket wrap to prevent urethrocutaneous fistula: an 8-year experience. The Journal of Urology.1995;153(2):472-473.

6. Snow BW. Use of tunica vaginalis to prevent fistulas in hypospadias surgery. The Journal of Urology. 1986;136(4):861-863.

7. Landau EH, Gofrit ON, Meretyk S, Katz G, Golijanin D, Shenfeld OZ, et al. Outcome analysis of tunica vaginalis flap for the correction of recurrent urethrocuteneous fistula in children. J Urol 2003;170:1596-9

8. Voges GE, Reidmiller H, Honenfellner R. Tunica vaginalis free grafts for closure of urethrocutaneous fistula. Urol Int 1990;45:88-99

9. Sharma N, Bajpai M, Panda SS, Verma A, Sharma M. Tunica vaginalis flap cover in hypospadias cripples: Our experience in a tertiary care center in India. Niger J Surg Sci 2014;24:7-11
10. Kadian YS, Rattan KN, Singh J, Singh M, Kajal P, Parihar D. Tunica vaginalis: An aid in hypospadias fistula repair: Our experience of 14 cases. Afr J Paediatr Surg 2011;8:164-7

11. Xue WY, Qu CB, Wang XL, Zhang FX, Kang CS. J Urol. 2003 Oct;170(4 Pt 2):1596-9

12. Routh JC, Wolpert JJ, Reinberg Y. Tunneled tunica vaginalis flap is an effective technique for recurrent urethrocutaneous fistulas following tubularized incised plate urethroplasty,J Urol. 2006 Oct;176(4 Pt 1):1578-80

13. Ahmed M. Khairi, Nour El-Kholi, Sherif M. Soliman, Ahmed Demairy Tunica Vaginalis Flap; A Feasible Second-Layer for Proximal Hypospadias Re-Do Annals of Pediatric Surgery, Vol3, No 1, January 2007 PP 44-47 